\title{
Comparative study of histopathology and immunohistochemistry of indefinite round cell cutaneous tumors and characterization of canine lymphoma
}

\author{
[Estudo comparativo de histopatologia e imuno-histoquímica de tumores indefinidos de células \\ redondas e caracterização de linfoma canino] \\ L.H.A. Machado ${ }^{1}$, M.I.P. Palumbo ${ }^{1 *}$, F.S. Zahn ${ }^{1}$, R.L. Amorim ${ }^{1}$, M.R. Farias ${ }^{2}$, J. Werner ${ }^{3}$, \\ R. Torres Neto ${ }^{1}$, J.C. Rodrigues ${ }^{1}$, F.C. Oliveira ${ }^{1}$ \\ ${ }^{1}$ Faculdade de Medicina Veterinária e Zootecnia - Universidade Estadual Paulista - FCAV-Unesp - Botucatu, SP \\ ${ }^{2}$ Pontifícia Universidade Católica do Paraná - PUCPR - Curitiba, PR \\ ${ }^{3}$ Autônomo
}

\begin{abstract}
With the purpose of shedding light on some doubts in veterinary oncology, the present article intends to compare the results of histopathological and immunohistochemical examinations of unspecific round cell neoplasia, to realize immunophenotyping of canine lymphoma cases, to establish the $\mathrm{T}$ or $\mathrm{B}$ origin of neoplastic cells, and to determine the degree of proliferation and apoptosis of lymphomas by immunohistochemistry. Of 11 animals presenting immunohistochemical diagnosis of lymphoma, five had been diagnosed as Lymphoma by HE staining of histopathological slides and six had been classified as unspecific round cell neoplasia. All cases submitted to immunohistochemical examination were T-cell lymphomas. There was a positive correlation between cell proliferation and apoptosis. The comparison among histopathological and immunohistochemical results obtained in the cases examined in the present study suggested that immunohistochemistry is essential for the differentiation of round cell neoplasia.
\end{abstract}

Keywords: dog, histopathology, immunohistochemistry, round cell neoplasia, lymphoma

\section{RESUMO}

Com o objetivo de sanar algumas dúvidas na área da oncologia veterinária, o presente artigo pretende comparar os resultados dos exames histopatológicos e imuno-histoquímicos de neoplasias de células redondas inespecíficas, realizar imunofenotipagem dos casos de linfoma canino e determinar o grau de proliferação e apoptose de linfomas. Dos 11 animais que apresentaram diagnóstico imuno-histoquímico de linfoma, cinco foram diagnosticados como linfoma por coloração HE das lâminas histopatológicas e seis foram classificados como neoplasia de células redondas inespecíficas. Todos os casos submetidos ao exame imuno-histoquímico foram de linfomas de células-T. Houve uma correlação positiva entre a proliferação celular e apoptose. A comparação entre os resultados histopatológicos e imuno-histoquímicos obtidos nos casos analisados sugeriu que a imuno-histoquímica é essencial para a diferenciação das neoplasias de células redondas.

Palavras-chave: cão, histopatologia, imuno-histoquímica, neoplasias de células redondas, linfoma

\section{INTRODUCTION}

Lymphoma is one of the most frequent neoplasias in dogs, which may also be found under the names lymphossarcoma and malignant lymphoma, and represents approximately $7-24 \%$ of all canine neoplasia and $83 \%$ of hematopoietic tumors (Teske et al., 1994).
One of the methods used to classify canine lymphoma is immunohistochemistry, which demonstrates the presence of cell type marking antigens (Milner et al., 1996). Its use in Veterinary Medicine is still restricting because of the high cost and the absence of specific markers in some cases (Fisher et al., 1995), although this reality is changing (Soares and Arias 1999).

Recebido em 5 de fevereiro de 2014

Aceito em 7 de agosto de 2014

* Autor para correspondência (corresponding author)

E-mail: palumboma11@yahoo.com.br 
Immunohistochemistry has proved to be an important tool in precise diagnosis (Dobson et al., 2001), making it possible to classify type B or $\mathrm{T}$ origin and characterize the degree of maturation of lymphoid neoplastic cells.

The technique has been used successfully in histological slides of paraffin- included tissue, making B-cell lymphomas with monoclonal antibody anti-mb1 (CD79a) and T-cell lymphomas with polyclonal antibody anti-CD3 (Bacchi and Gown, 1993; Fournel- Fleury et al., 1997; Fournel- Fleury et al., 2002; Bhang et al., 2006; Cardoso et al., 2006).

Because canine lymphoma has similarities with non-Hodgkins human lymphoma, it is possible to use its cytohistological and immunophenotypic classifications in canine lymphoma, associating these data with clinical findings, thus improving treatment and the determination of prognosis and survival time in animals (Fisher et al., 1995; Kiupel et al., 1999). Also, the results obtained in animals may be used as experimental models for human oncology (MacEwen, 1990).

Tumor growth is determined by three main factors: cell cycle length, percentage of proliferating cells and the number of cells lost by apoptosis (Franks, 1990). Cell proliferation, with mass formation, is one of the characteristics of neoplasia, which does not depend on the primary cause, as a direct consequence of disturbance in the control of cell cycle (Bacchi and Gown, 1993). Detection and quantification of proliferating cells have been considered important prognostic parameters in oncology, and may be used to identify neoplasia or to evaluate its malignancy (Bacchi and Gown, 1993; Rabenhorst et al., 1993).

In canine mast cell tumors, the evaluation of markers for cell proliferation has been suggested as an indicator of prognosis, associated to the classification by traditional histopathological criteria (Teske et al., 1994). The consulted literature, however, did not point this correlation for the indication of prognosis in canine lymphoma.

As knowledge in biology and biochemistry about the regulation of mitosis was restricting, cell proliferation was estimated only by the counting of mitotic figures. The advent of techniques for identification of proteins present exclusively in cells brought light to the studies in cell proliferation, with the use of in situ methods, that present the huge advantage of measuring the proliferative activity without damaging the tissue, which allows performing the histological analysis and the differentiation between neoplastic and non-neoplastic cells (Bacchi and Gown, 1993).

One method that is currently used is immunohistochemistry, which uses antibodies against specific antigens for proliferative cells (Rabenhorst et al., 1993), thus determining the proliferative activity by cell marking, and may also be associated to tumoral response to chemotherapy. Studies have shown that tumors with an elevated growth ratio are more susceptible to drugs and proliferative activity has been considered in humans to identify those patients that will need adjuvant therapy besides surgical removal of tumors (Quinn and Wright, 1990).

The mouse anti-Ki-67 monoclonal antibody clone MIB-1 has been used as a marker of cell proliferation in many tumors, both in humans and animals. The evaluation of cell proliferation by $\mathrm{Ki}-67$ index is highly predictive of the behavior of several tumors (Abadie et al., 1999; Sakai et al., 2002).

In canine mast cell tumors, the immunoreactivity for $\mathrm{Ki}-67$ is correlated to the histological grade, being useful in the evaluation of cell proliferation and in the determination of the degree of cell differentiation (Teske et al., 1994). Histiocytoma is one of the most important and challenging differential diagnosis of lymphoma (Bhang et al., 2006; Cardoso et al., 2006), corresponding to $19.6 \%$ of cutaneous tumors (Gross et al., 1992).

Another important variable related to the biological behavior of proliferative lesions is the index of apoptosis (Sano et al., 2004). Apoptosis has been studied by the expression of caspase, which are enzymes directly related to apoptosis, being present in most cells' cytoplasm in the inactive form, as a single chain of polypeptides that is broken when apoptosis occurs (Sano et al., 2004). The inhibition of caspase activity may delay or impair cell death by apoptosis (Nicholson, 1999). 
The most studied caspase is caspase- 3 , known to be related to apoptosis in many hematoproliferative disturbs in humans; both the level of caspase-3 expression and the form of its intracytoplasmic marking are related to tumoral progression. Highly aggressive neoplasia present lower caspase-3 cytoplasmic expression than low grade neoplasia (Porter and Jänicke, 1999).

The present article aimed to compare the results of histopathological and immunohistochemical examinations of unspecific round cell neoplasia, to realize immunophenotyping of canine lymphoma cases, to establish the $\mathrm{T}$ or B origin of neoplastic cells, to determine the degree of proliferation and apoptosis of lymphomas by immunohistochemistry.

\section{MATERIAL AND METHODS}

Cases of cutaneous lymphoma and unspecific round cell neoplasia were selected in histopathological archives. Initial selection, as well as initial histopathological examinations were performed at Werner and Werner Veterinary Pathology Laboratory and immunohistochemical examinations were performed at the Service of Veterinary Pathology of FMVZ-Unesp, Botucatu.

The fragments were identified and fixed in $10 \%$ buffered formalin, then submitted to histological routine procedures and included in paraffin. Histological cuts of $3 \mu \mathrm{m}$ were stained by Hematoxylin-Eosin(HE) (Luna, 1968) and observed under light microscopy.

The study of tumor cell lines was performed using standardized techniques at the laboratory of the Service of Veterinary Pathology of FMVZ - UNESP - Botucatu, with the following panel of antibodies: Anti-CD3, Anti-CD79a, Caspase-3 and MIB-1. For Anti-CD3 and anti CD-79a antibodies, only positive and negative criteria were established; for caspase- 3 and MIB-1, cells were counted in all slides, whether immunolabeled (positive) or not (negative).

Data were submitted to Spearman correlation coefficient, which is applicable to nonparametric variables, and to Pearson coefficient. The results of the Pearson test were not presented because no correlation was observed.

\section{RESULTS}

The results of histological and immunohistochemical examinations of the confirmed cases of lymphoma and nonconfirmed cases of cutaneous lymphoma are presented in Table 1 and 2, respectively (Table 1, Table 2).

Table 1. Results of histological and immunohistochemical evaluation of confirmed cases of canine lymphoma

\begin{tabular}{|c|c|c|c|c|c|c|c|c|}
\hline \multirow[b]{2}{*}{ Dog } & \multirow[b]{2}{*}{$\mathrm{HE}$} & \multicolumn{2}{|c|}{ MIB } & \multicolumn{2}{|c|}{ Caspase } & \multirow{2}{*}{$\begin{array}{c}\text { CD3 } \\
\\
0 \\
\stackrel{0}{0} \\
0\end{array}$} & \multirow{2}{*}{$\begin{array}{l}\text { CD79 } \\
\stackrel{0}{:} \\
\stackrel{0}{0} \\
\stackrel{0}{0}\end{array}$} & \multirow[b]{2}{*}{$\begin{array}{c}\text { Immunohistochemical } \\
\text { diagnosis }\end{array}$} \\
\hline & & 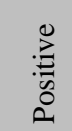 & 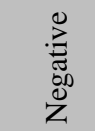 & 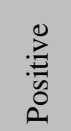 & 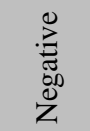 & & & \\
\hline 1 & Lymphoma & 223 & 53 & 10 & 171 & $\bar{X}$ & & T-cell lymphoma \\
\hline 2 & Lymphoma & 55 & 159 & 0 & 0 & $\mathrm{X}$ & & T-cell lymphoma \\
\hline 3 & IRCN & 28 & 110 & 40 & 184 & $\mathrm{X}$ & & T-cell lymphoma \\
\hline 4 & IRCN & 2 & 387 & 4 & 253 & $\mathrm{X}$ & & T-cell lymphoma \\
\hline 5 & IRCN & 57 & 270 & 110 & 160 & $X$ & & T-cell lymphoma \\
\hline 6 & IRCN & 125 & 274 & 9 & 242 & $\mathrm{X}$ & & T-cell lymphoma \\
\hline 7 & IRCN & 110 & 159 & 8 & 223 & $X$ & & T-cell lymphoma \\
\hline 8 & IRCN & 11 & 315 & 11 & 264 & $\mathrm{X}$ & & T-cell lymphoma \\
\hline 9 & Lymphoma & 51 & 142 & 35 & 74 & $\mathrm{X}$ & & T-cell lymphoma \\
\hline 10 & Lymphoma & 193 & 215 & 7 & 263 & $\mathrm{X}$ & & T-cell lymphoma \\
\hline 11 & Lymphoma & 113 & 195 & 24 & 230 & $X$ & & $\mathrm{~T}$-cell lymphoma \\
\hline Total & & 968 & $2279^{\mathrm{a}}$ & 258 & $2064^{\mathrm{a}}$ & & & \\
\hline
\end{tabular}

$\mathrm{HE}=$ hematoxylin/eosin. IRCN = inespecific round cell neoplasia. Same letter in a row indicates positive correlation between variables $(r=0.66059, \mathrm{P}=0.0269)$. 
Table 2. Results of histological and immunohistochemical evaluation of non-confirmed cases of cutaneous lymphoma

\begin{tabular}{cccccccc}
\hline Cão & HE diagnosis & \multicolumn{2}{c}{ MIB } & \multicolumn{2}{c}{ Caspase } & CD3 & CD79 \\
\hline & & Negative & Positive & Negative & Positive & Negative & Negative \\
\hline 1 & Round cell neoplasia & 80 & 290 & 14 & 330 & X & X \\
2 & Round cell neoplasia & 53 & 615 & 6 & 387 & X & X \\
3 & Plasma cell neoplasia & 112 & 315 & 20 & 392 & X & X \\
4 & Round cell neoplasia & 423 & 156 & 13 & 360 & X & X \\
\hline
\end{tabular}

\section{DISCUSSION}

The evaluation of fine needle aspirates by a qualified pathologist may be adequate to diagnose canine lymphoma, but conclusive histological confirmation is still recommended (Vail, 2004). From 11 animals presenting immunohistochemical diagnosis of lymphoma, five had been diagnosed as Lymphoma by HE staining of histopathological slides and six had been classified as unspecific round cell neoplasia (IRCN), thus demonstrating that, in many cases, more specific diagnostic techniques are necessary to allow better treatment and prognosis establishment.

Immunohistochemistry has shown to be an important tool in precise disease diagnosis (Dobson et al., 2001), making it possible to classify either T or B-cell Lymphoma and also the degree of neoplastic lymphoid cell maturation. The technique has been successfully applied in paraffin-included histological material, marking B-cell lymphomas with monoclonal antibody anti-mb1 (CD79a) and T-cell lymphomas with polyclonal antibody anti-CD3 (Fournel-Fleury et al., 1997; 2002; Bhang et al., 2006; Cardoso et al., 2006; Arespacochaga et al., 2007). According to the literature, most canine lymphomas are type B (Teske et al., 1994; Fournel-Fleury et al., 1997; Arespacochaga et al., 2007), but in the present study, all cases submitted to immunohistochemical examination were T-cell lymphomas, as they were marked only by polyclonal antibody anti-CD3. In a study of 40 cases of canine lymphoma, similar proportions (42.5\% each) of $\mathrm{T}$ and $\mathrm{B}$-cell cases were reported and $15 \%$ of mixed $\mathrm{T} / \mathrm{B}$ lymphomas were also observed (Suzano et al., 2008). This difference among reports may be due to the fact that in the present study, all the 11 cases were cutaneous lymphomas, while in the other reports extracutaneous lymphomas, considered to have better prognoses, were also included.

The mouse anti-Ki-67 monoclonal antibody clone MIB-1 has been applied as a marker for cell proliferation in many tumors, both in humans and animals. Apoptosis has been evaluated by caspase expression, which is directly related to apoptosis and is present in most cells' cytoplasm in inactive forms that, when the single polypeptides chain is broken, initiates apoptosis (Luna, 1968). In the present study there was a positive correlation between cell proliferation and apoptosis. Further studies are already planned in order to associate immunohistochemical results and clinical response to chemotherapy in order to establish whether this correlation could reflect in prognosis. The presence of apoptosis may facilitate this response, making the tumor more susceptible to chemotherapy.

\section{CONCLUSION}

The comparison among histopathological and immunohistochemical results obtained in the cases examined in the present study suggested that immunohistochemistry is essential for the differentiation of round cell neoplasia. More studies on cutaneous lymphomas are necessary to determine which are the most involved cell types, their proliferative and apoptotic characteristics and the association of those findings with clinical evolution of the patient. 


\section{REFERENCES}

ABADIE, J.J.; AMARDEILH, M.A.; DELVERDIER, M.E. Immunohistochemical detection of proliferating cell nuclear antigen and $\mathrm{Ki}-67$ in mast cell tumors from dogs. J. Am. Vet. Med. Assoc., v.215, p.16291633, 1999.

ARESPACOCHAGA, A.G.; SCHWENDENWEIN, I.; WEISSENBÖCK, H. Retrospective study of 82 cases of canine lymphoma in Austria based on the Working Formulation and Immunophenotyping. J. Comp. Pathol., v.136, p.186-192, 2007.

BACCHI, C.E.; GOWN, A.M. Detection of cell proliferation in tissue sections. Braz. J. Med. Biol. Res., v.26, p.677-687, 1993.

BHANG, D.H.; CHOI, U.S.; KIM, M.K. et al. Epitheliotropic cutaneous lymphoma (mycosis fungoides) in a dog. J. Vet. Sci., v.7, p.97-99, 2006.

CARDOSO, M.J.L.; TORRES NETO, R.; AMORIM, R.L. et al. Micose fungoide em um cão. Vet. e Zootec. v.13, p.137-146, 2006.

DOBSON, J.M.; BLACKWOOD, L.B.; MCINNES, E.F. et al. Prognostic variables in canine multicentric lymphossarcoma. J. Small Anim. Pract., v.42, p.377384, 2001.

FISHER, D.J.; NAYDAN, D.; WERNER, L.L. et al. Immunophenotyping lymphomas in dogs: a comparison of results from fine needle aspirate and needle biopsy sample. Vet. Clin. Pathol., v.24, p.118123, 1995.

FOURNEL-FLEURY, C.; MAGNOL, J.P.; BRICAIRE, P. et al. Cytohistological and immunological classification of canine malignant lymphomas: comparison with human non-Hodking's lymphomas. J. Comp. Pathol., v.117, p.35-59, 1997.

FOURNEL-FLEURY, C.; PONCE, F.; FELMAN, P. et al. Canine T-cell Lymphoma: a morphological, immunological, and clinical study of 46 new cases. Vet. Pathol. v.32, p.92-109, 2002.

FRANKS, L.M. O que é câncer? In: FRANKS, L.M.; TEICH, N. (Eds). Introdução à Biologia Celular e Molecular do Câncer. São Paulo: Roca, 1990. p.1-12.

GROSS, T.L.; IRHKE, P.J.; WALDER, E.J. Veterinary Dermatopathology: a macroscopic and microscopic evaluation of canine and feline skin disease. St Louis: Mosby Year Book, 1992. p.519.

KIUPEL M.; TESKE, E.; BOSTOCK D. Prognostic factors for treated canine malignant lymphoma. Vet. Pathol., v.36, p.292-300, 1999.
LUNA, L.G. Manual of Histological Staining Methods of Armed Forces Institute of Pathology. Washington, D C: McGraw Hill, 1968. 258p.

MACEWEN, E.G. Spontaneous tumors in dogs and cats: models for the study of cancer biology and treatment. Cancer and Metastasis Rev., v.9, p.125-35, 1990.

MILNER, R.J.; PEARSON, J.; NESPIT, J.W. et al. Immunophenotypic classification of canine malignant lymphoma on formalin-fixed paraffin wax-embedded tissue by means of CD3 and CD79a cell markers. $J$. Vet. Res., v.63, p.309-313, 1996.

NICHOLSON, D.W. Caspase structure, proteolytic substrates and function during apoptotic cell death. Cell Death Differ. v.6, p.1028-1042, 1999.

PORTER, A.G.; JÄNICKE, R.U. Emerging roles of caspase-3 in apoptosis. Cell Death Differ. v.6, p.99104, 1999.

QUINN, C.M.; WRIGHT, N.A. The clinical assessment of proliferation and growth in human tumors: evaluation of methods and applications as prognostic variables. J. Pathol., v.160, p.93-102, 1990.

RABENHORST, S.H.; BURINE, R.C.; SCHMITT, F.C.L. Marcadores da proliferação celular. Rev. Bras. Patol. Clin., v.29, p.24-28, 1993.

SAKAI, H.; NODA, A.; SHIRAI, N. et al. Proliferative Activity of Canine Mast Cell Tumours Evaluated by Bromodeoxyuridine Incorporation and Ki-67 Expression. J. Comp. Pathol., v.127, p.233-238, 2002.

SANO, J.; OGUMA, K.; KANO, R. et al. Characterization of canine caspase-3. J. Vet. Med. Sci., v.66, p.563-567, 2004.

SOARES, F.A.; ARIAS, V.E.A. Linfomas não Hodgkin de Células T, In: ALVES, V.A.F.; BACCHI, C.E.; VASSALLO, J. (Eds). Manual de Imunohistoquímica. Sociedade Brasileira de Patologia, São Paulo, SP. 1999. p.141-151.

SUZANO, S.M.C.; SEQUEIRA, J.L.; PESSOA, A.W.P. et al. Proliferação celular nos linfomas caninos. Braz. J. Vet. Res. Anim. Sci., v.43, p.313-319, 2008.

TESKE, E.; HEERDE, P.; RUTTEMAN, G.R. et al. Prognostic factors for treatment of malignant lymphoma in dogs. J. Am. Vet. Med. Assoc., v.205, p.722-1728, 1994.

VAIL, D.M. Tumores hematopoiéticos. In: ETTINGER, S.J.; FELDMAN, E.C. (Eds), Tratado de Medicina Interna Veterinária: doenças do cão e do gato. $5^{\text {th }}$ ed. Rio de Janeiro: Guanabara Koogan, 2004. p.538-555. 